\title{
Severity of Viral Diseases and Types of Weeds as Alternative Viral Hosts in Dioscorea Fields in Southern Guinea Savannah Agroecology of Nigeria
}

\author{
T.H. Aliyu ${ }^{1 *}$, F.O. Takim², L.K. Olatinwo ${ }^{3}$, O. Arogundade ${ }^{4}$, K.F. Omotesho ${ }^{5}$ and \\ D.A.Oladoja ${ }^{1}$
}

\begin{abstract}
The incidence and severity of viruses infecting yam and weeds were determined on 60 Dioscorea farms in Southern Guinea Savannah Agroecology of Kwara State, North-Central Nigeria. Double Antigen Sandwich EnzymeLinked Immunosorbent Assay (DASELISA) was used as a serological technique to detect Yam mosaic virus (YMV) and Cucumber mosaic virus (CMV) on Dioscorea and weeds collected from the farms. The survey indicated virus incidence on Dioscorea between $62.8 \%$ and $100 \%$ and virus severity between 2 and 5 score values. DAS-ELISA
\end{abstract}

${ }^{1}$ University of Ilorin, Faculty of Agriculture, Department of Crop Protection, Nigeria.

${ }^{2}$ University of Ilorin, Faculty of Agriculture, Department of Agronomy, Nigeria.

${ }^{3}$ Kwara State University Malete, Department of Agricultural Economics and Extension, Nigeria.

${ }^{4}$ National Horticultural Research Institute, Ibadan, Nigeria.

${ }^{5}$ Department of Agricultural Extension and Rural Development, University of Ilorin, Nigeria.

*aliyutaiyehussein@yahoo.com

iD http://orcid.org/0000-0002-8638-1742

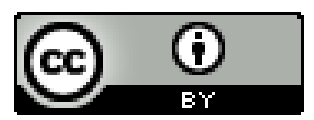

This article is published under the terms of the Creative Commons Attribution 4.0 International License which permits unrestricted use, distribution and reproduction in any medium provided the original author and source are credited. detected YMV in all the Dioscorea leaf samples and mixed infection of YMV with CMV in 13 samples. Twenty-nine (29) weed species were found to be predominant on Dioscorea fields which comprised of annuals and broadleaves. DAS-ELISA revealed high YMV titer values for the weed species, Eclipta alba, Euphorbia heterophylla, Oldenlandia herbacea, Cynodon dactylon and Phyllantus amarus. However, CMV was not found in any of the sampled weed species. The study showed a high occurrence of viruses on Dioscorea and the preponderance of weeds which could serve as vectors of viruses. There is a need for efficient management strategies for virus and weed elimination within and around yam fields which will invariably be an attraction to farmers with limited resources for optimum yam production.

Keywords: Ecology, Farming household, Virus transmission, Weeds, Yam production

\section{INTRODUCTION}

Yam (Dioscorea spp.) is very important in food security and poverty reduction in Nigeria, as it is consumed in a variety of ways. The major producing states in 
Nigeria are Adamawa, Benue, Cross River, Delta, Edo, Ekiti, Imo, Kaduna, Kwara, Ogun, Ondo, Osun, Oyo, and Plateau (Akanji et al., 2003). The important yam species grown in Africa are Dioscorea rotundata (white yam), Dioscorea cayenensis Lam (yellow yam), Dioscorea dumetorum (bitter yam), Dioscorea alata (water yam), Dioscorea bulbifera (aerial yam) and Dioscorea esculentus Lour (Chinese yam) (Asala and Ebukiba, 2016). The variety $D$. rotundata is the principal commercial yam and constitutes about $80 \%$ of the total yam produced in Nigeria (Degras, 1993).

Yam may be cooked or fried with rice, beans, plantain, sweet potato, lamb, chicken and butternut as squash soup (Umar et al., 2006). The tubers may be peeled and sliced into tiny pieces and dried to very low moisture contents and milled into yam flour and flakes (Udoh et al., 2005) and in some communities, yam is perceived as a religious, social, and cultural crop (Obidiegwu and Akpabio, 2017). More importantly, yam tubers have organoleptic qualities which make them the preferred carbohydrate staple and can contribute up to 350 dietary calories per person each day (Osei et al., 2019). Tubers of Dioscorea are used as "body refrigerant" during summer and are also used to treat diarrhea (Dutta, 2015). Therefore, improving yam productivity can increase food production and farmers' income in the producing areas, particularly in West Africa (Hgaza et al., 2010).

Diseases constitute a major constraint to global yam production and are responsible for significant yield losses (Kolombia et al., 2017). Yam viruses have been reported in most of the yam growing areas of West Africa (Odu et al., 1999), causing a reduction in yield and restriction of international exchange of germplasm (Ita et al., 2020). In Nigeria, yam mosaic virus and cucumber mosaic virus are the most prevalent ones that occurred on $78 \%$ of yams (Atiri et al., 2003).

Virus disease pandemics and major epidemics affected plants are cultivated not only to feed humankind and livestock but also to provide other benefits such as fibre, ornamental plants, or medicinal products. The role of weeds in the occurrence and spread of virus diseases is an integral part of the ecological aspect of virus transmission. Weeds have the potential to alter the function of ecosystems either as pests themselves and are 
potential sources of primary viral inoculum of both known and unidentified virus species. This ensures the paramount importance of weeds in the management of virus diseases for optimum yam production (Asala et al., 2014; Rybicki, 2015).

The objectives of the study were to evaluate the incidence and severity of virus diseases on yam fields; identify the predominant weed species on yam fields and detect the occurrence of Yam Mosaic Virus (YMV) and Cucumber Mosaic Virus (CMV) on yam leaf and weed samples in the Southern Guinea Savannah Agroecology of Kwara State, Nigeria.

\section{MATERIALS AND METHODS}

\section{Sampling Technique and Estimation of Virus Incidence and Severity}

A virus disease survey was carried out on sixty (60) yam fields with a farm size not less than 0.2 hectares across the 3 districts of Kwara State, Southern Guinea Savannah Agroecology of Nigeria. The predominant yam species grown in the study area are white yam (Dioscorea rotundata) and water yam (Dioscorea alata). The survey of farmer's fields was done in the months between
August to January 2018 and 2019. The size of an average yam heap in the study area was about $0.77 \mathrm{~m}^{2}$. Yams were manually planted under rain-fed conditions with no pesticides or fertilizers applied.

Virus disease incidence was estimated on fifty (50) plant observations per field based on typical yam virus symptoms expressed on leaves (Chaube and Pundhir 2005). Observations on the 50 plants were taken by walking across a "W" shaped path in a field, with 10 plants per side spaced at an equal distance of $0.75 \mathrm{~m} \mathrm{X}$ $0.25 \mathrm{~m}$ from each other. Percentage virus incidence was calculated based on the formula derived from Abraham et al. (2020), as shown below formula;

Percentage incidence $=$ Number of infected

(symptomatic

$$
\frac{\text { plants) }}{\text { Total number of sampled }} \times 100 .
$$

The collected data on virus incidence were subjected to analysis of variance (ANOVA) and treatment means where significant, were separated using the New Duncan Multiple Range Test at 5\% level of probability. 
The severity of symptomatic plants (Figure 1) was assessed by rating fifty plants from 1 to 5 scale, where $1=$ plant with no visible symptoms on the leaves; $2=$ symptoms on $1-24 \%$ of infected leaves; $3=$ symptoms on $25-50$ $\%$ of infected leaves; $4=$ symptoms on $51-75 \%$ of infected leaves and $5=$ symptoms on more than $75 \%-100 \%$ of infected leaves (Toualy et al., 2014).

\section{Collection of Yam and Weed Samples and Virus Identification}

Symptomatic and asymptomatic 20 yam leaves (2-3 months old) were randomly collected from each yam field at the onset of the rainy season (AugustOctober). The predominantly grown yam species in the study area were Dioscorea rotundata and Dioscorea alata. The weeds on the farms and adjoining areas of the farms were collected and enumerated in a $50 \mathrm{~m} \times 50 \mathrm{~m}$ area using a random sampling technique in which ten points were located for the placement of $1 \mathrm{~m}^{2}$ wooden quadrat (Awodoyin et al., 2013). The weed species and other low-growing plants within each quadrat were identified to species level using the weed identification manual of Akobundu et al. (2016). The collected yam leaves and weed samples were separated, sealed in dispenser sachets labeled and preserved over ice prior to serological analysis in the laboratory.

The test protocol for the detection and identification of the viruses infecting samples were carried out at the Virology Laboratory of the International Institute for Tropical Agriculture (IITA), Ibadan, Nigeria using Double Antigen Sandwich Enzyme-Linked Immunosorbent Assay (DAS-ELISA) (Kumar, 2009). The optical density (OD) values were measured at an absorbance of $405 \mathrm{~nm}$ (A405) after one hour in each well, using a BIO-RAD Microplate Reader (ELx800, Universal Microplate Reader). An optical density value greater than twice the mean of the negative controls (virus-free plants) was considered positive for a particular virus (Preller $e t$ al., 2018).

\section{RESULTS}

Incidence and Severity of Virus Disease on Yam Fields

The incidence and severity of virus disease on yam in the study are shown in Table 1. The results indicated significant differences $(P<0.05)$ on virus incidence among districts ranged 
from $62.8 \%$ in Omupo (Kwara south district) to $100 \%$ in the respective locations of Kosubosu, Lafiagi (Kwara north district), Osin/Agogo, Aleara, Lasoju, Ago-Oja, Budo Adan, Molete, Oloru (Kwara central district), Idofian,
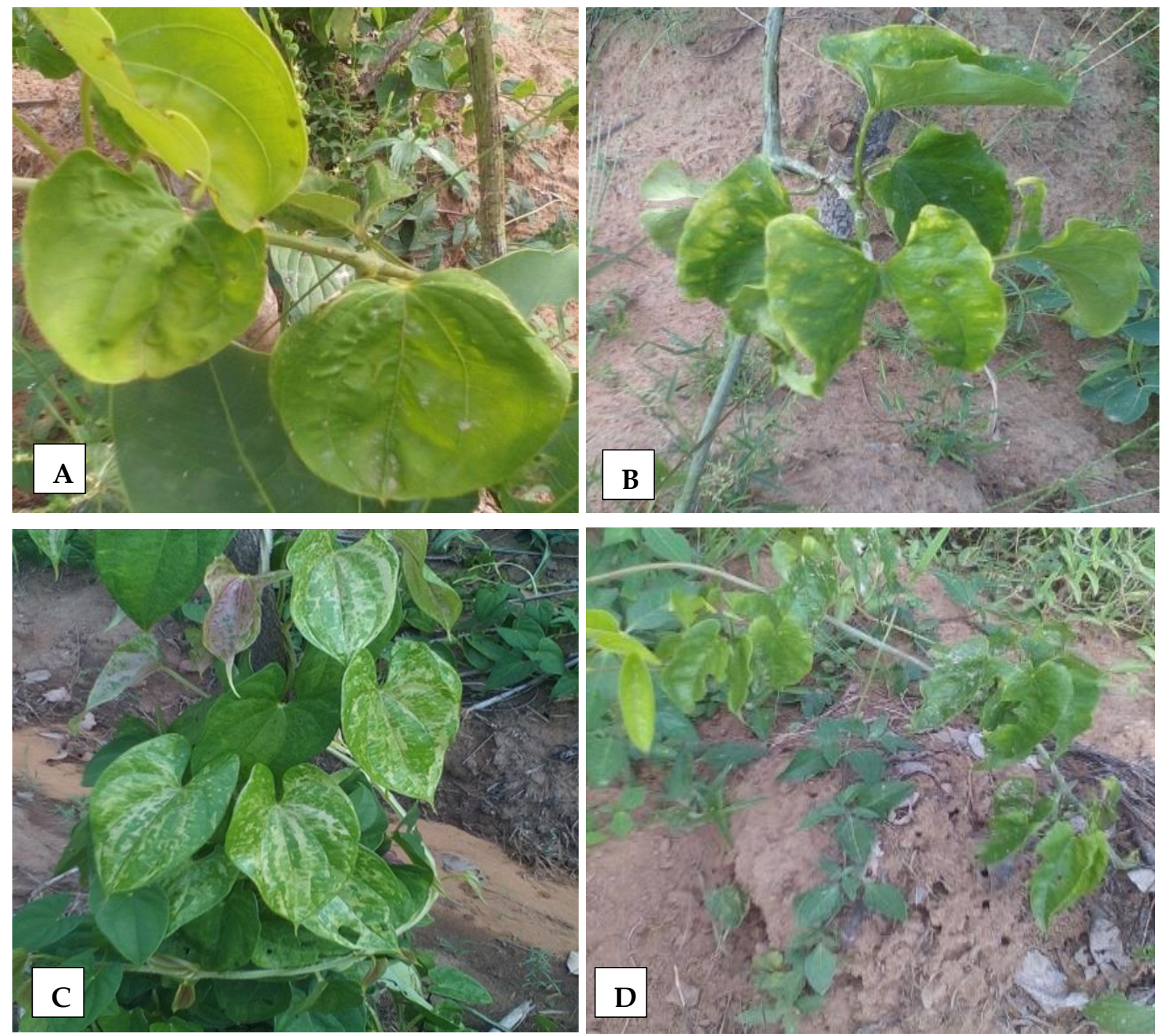

Figure 1. Viral disease symptoms on Discorea rotundata (A and B) and Dioscorea alata (C and D) observed in surveyed farms; (A) severe mosaic bleached leaves in Dioscorea rotundata, (B) leaf curl and chlorotic mosaic in Dioscorea rotundata, (C) mottled leaves and vein banding in Dioscorea alata and (D) Dioscorea alata manifesting stunted growth, reduction in leaf size and shoe stringing symptoms. 
T.H. Aliyu et. al.

Table 1. Incidence and severity of viruses on yam

\begin{tabular}{llcl}
\hline Farm location & District & \% Incidence & Severity \\
\hline Wode & North & 95.8 & 3 \\
Magya & North & 83.8 & 3 \\
Dzwajiwo & North & 80.1 & 3 \\
Kaiama & North & 82.0 & 2 \\
Alapa & North & 84.0 & 4 \\
Okuta & North & 83.3 & 4 \\
Gobi & North & 81.6 & 3 \\
Gwanara & North & 93.3 & 5 \\
Kosubosu & North & 100 & 3 \\
Teshe & North & 86.8 & 3 \\
Bioweite & North & 88.5 & 4 \\
Igbogi & North & 94.9 & 5 \\
Sebo & North & 96.9 & 5 \\
Kemanji & North & 98.3 & 2 \\
Ilesha & North & 95.6 & 2 \\
Kuliji & North & 93.2 & 5 \\
Bani & North & 97.5 & 5 \\
Woro & North & 95.5 & 4 \\
Shonga & North & 98.4 & 4 \\
Lafiagi & North & 100 & 4 \\
Osin/Agogo & Central & 100 & 3 \\
Aleara & Central & 100 & 3 \\
Afon & Central & 97.9 & 1 \\
Lasoju & Central & 100 & 2 \\
Owode & Central & 99.7 & 2 \\
Onire & Central & 88.3 & 3 \\
Sapati Ile & Central & 98.3 & 3 \\
Ago Oja & Central & 100 & 4 \\
Budo Alfa & Central & 89.0 & 4 \\
Fufu & Central & 99.9 & 3 \\
Laduba & Central & 96.5 & 3 \\
Temidire & Central & 98.8 & 2 \\
Gaa Adio & Central & 99.8 & 5 \\
Budo Adan & Central & 100 & 5 \\
Gaa Jawuro & Central & 83.3 & 5 \\
Lanwa & Central & 86.9 & 4 \\
Molete & Central & 100 & 4 \\
Oloru & Central & 100 & 3 \\
Paiye & Central & 99.5 & 3 \\
Ejidon Gari & Central & 89.9 & 3
\end{tabular}




\begin{tabular}{llll} 
Omupo & South & 62.8 & 3 \\
Ilofa & South & 77.9 & 1 \\
Osi & South & 81.1 & 1 \\
Ajase-Ipo & South & 79.9 & 3 \\
Oke-Onigbin & South & 88.5 & 3 \\
Edidi & South & 91.1 & 3 \\
Eruku & South & 93.3 & 4 \\
Obo & South & 98.8 & 5 \\
Araromi-opin & South & 89.9 & 5 \\
Agunjin-Ora & South & 91.1 & 4 \\
Idofian & South & 100 & 4 \\
Igbaja & South & 100 & 3 \\
Ijara-Isin & South & 99.9 & 3 \\
Esie-Ijan & South & 98.7 & 1 \\
Offa & South & 91.1 & 3 \\
Ira & South & 80.9 & 5 \\
Ora & South & 85.5 & 5 \\
Isapa & South & 99.8 & 4 \\
Omu-Aran & South & 91.7 & 4 \\
Koro & South & 73.2 & 5 \\
\hline
\end{tabular}

The virus severity ranged from 2 to 5 score values for all the locations in the districts. The symptoms observed were mostly mild mosaic, mottling, yellowing and mild necrosis on few leaves to severe mosaic and severe stunting of the entire yam plants. The highest severity (5) were recorded in 5 locations in Kwara north (Gwanara, Igbobi, Sebo, Kuliji and Bani); 3 locations in Kwara central (Gaa Adio, Budo Adan and Gaa jawuro), and 5 locations in Kwara south (Obo, Araromi-opin, Ira, Ora and Koro). There were however no significant differences at $P=0.05$ among the virus severity of Kwara north (3.4), Kwara central (3.7) and Kwara south (3.3) districts.

\section{Virus Detection on Yam Leaf Samples}

The serological detection of YMV and CMV on yam leaf samples is presented in Table 2 and collected weed samples with viral symptoms are shown in Figure 2. The results indicated the detection of YMV in all yam samples. The result further indicated that there was a mixed viral infection of the two viruses in $21.7 \%$ of samples. These were in samples from Dzwajiwo, Alapa, Teshe, Sebo, Woro, Lafiagi (Kwara north district), Lasoju, Fufu, Gaa Adio, Molete (Kwara central district), Eruku, Igbaja and Koro (Kwara south district). 
Predominant Weed Species and Virus Occurrence

A total of 29 weed species belonging to 26 genera with 11 families were identified to be predominant on yam fields in the study (Table 3). Four weed families encountered have made up to $68.97 \%$ of the weed spectrum and Asteraceae and Poaceae were the predominant families with 7 and 6 weed species enumerated, respectively. The weed spectrum had $62.07 \%$ broadleaves, $20.69 \%$ grasses and 13.79 $\%$ sedges. In terms of the life cycle, 62.07 $\%$ were annuals, $27.59 \%$ were perennials and $10.34 \%$ were either annuals or perennials.

The DAS-ELISA revealed the absence of CMV in all tested weed species, however, YMV was detected on 9 weed species. The majority of the weeds found harboring YMV were either broadleaves or annuals with the following titre values; Eclipta alba L. (0.753), Euphorbia heterophylla L. (0.611), Oldenlanda herbacea (L.) Roxb (0.471), Cynodon dactylon (L.) Pers (0.437), Phyllanthus amarus Schum \& Thonn (0.429), Mariscus flabelliformis Kunth (0.402), Spigelia anthelmia L. (0.310), Melampodium divaricatum L. (0.304) and Veronica parrottetii Sch.Bip (0.289).

\section{DISCUSSION}

The study reported a high incidence and severity of viral infection in the yam fields. The field infections occurred as single and mixed virus pathogens of the tested YMV and CMV. This is an indication that yam productivity in the study area can be severely compromised by the impact of these yam viruses. These findings are also supported by experimental submissions of Odu et al. (1999), Yeyeh et al. (2014) and Asala et al. (2012). Variation in virus incidence between locations detected in the study can be elucidated by dynamics such as initial inoculum sources, host species and vectors occurring in the respective locations. In addition, the use by farmers of virus-contaminated yam setts and lack of diagnostic tools could also be contributory factors. This is because the natural transmission of viruses that can be accentuated by infected planting materials and vectors as posited by Eni et al. (2013).

The presence of weeds in close proximity to yam fields has been shown 

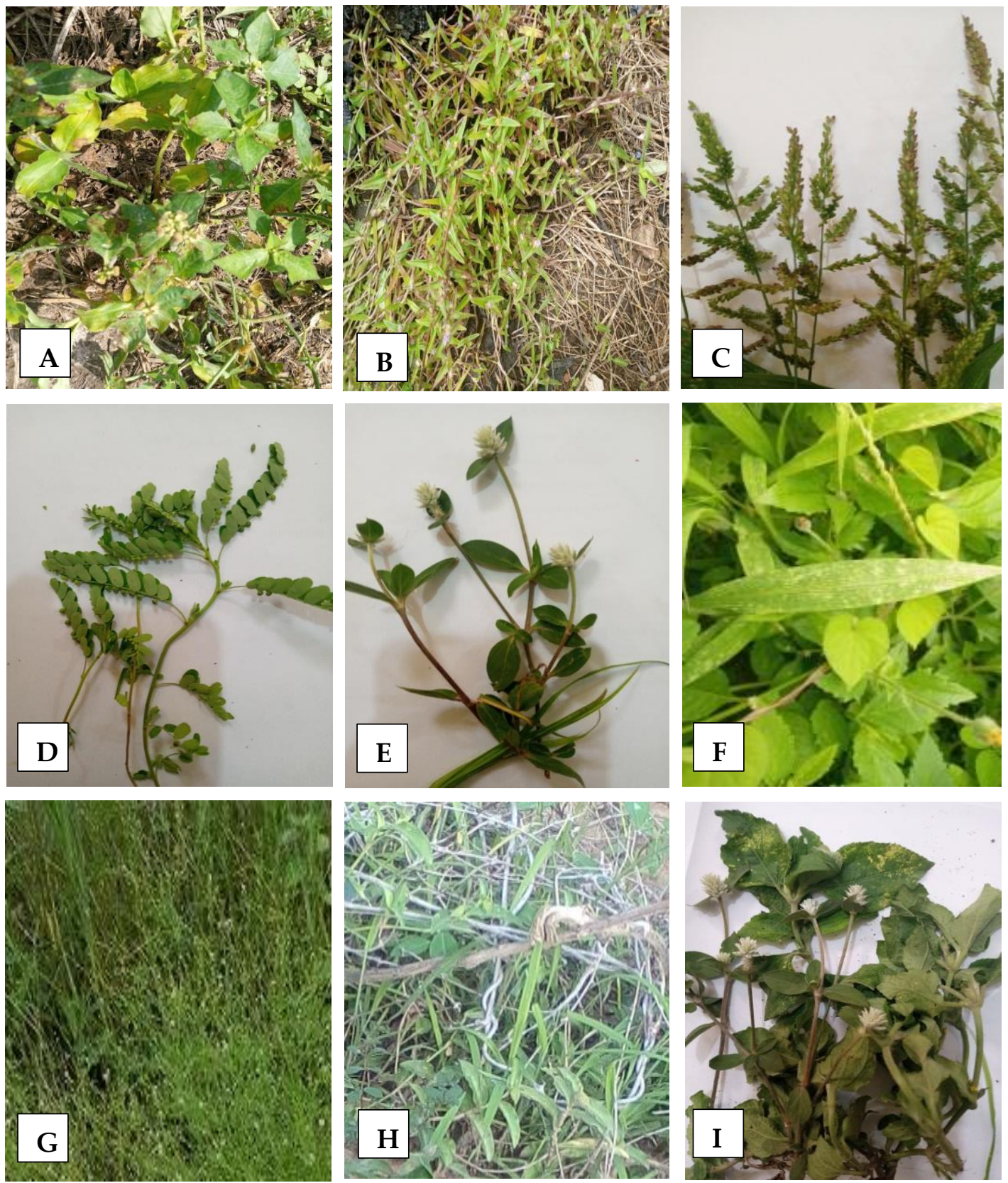

Figure 2. Samples of weeds with viral symptoms that were ELISA positive for YMV; (A) Euphorbia heterophylla, (B) Eclipta alba, (C) Mariscus flabelliformis, (D) Phyllanthus amarus, (E) Spigelia anthelmia, (F) Cynodon dactyla, (G) Oldenlanda herbacea, (H) Vernonia parrottetii and (I) Melampodium divaricatum

to be associated with diminished tuber yield. The prominent weed species identified on yam fields in the study area are in the family of Poaceae and Asteraceae. This finding is in agreement with reports of Singh et al. (1986) and 
Ekanayake and Asiedu (2003). The presence of large weed species is an indication of a reservoir of viruses which can thus be transmitted from weed species to yam and other arable crops. This claim is supported by Odedara (2008) and Gumedzeo (2002).

The study detected YMV occurrence on the weed samples. This result is similar to reports by Mukhtar et al. (2012) that also identified yam mosaic virus to be the dominating virus on weed samples around yam fields. It is the view of Groves et al, (2002) and Hily et al. (2014) who indicated that plant viruses require alternate hosts to continue the virus-host-vector association. The majority of plant viruses that cause disease in agricultural crops rely on biotic vectors for transmission and survival. It is therefore an indication that the weed species found positive to YMV could serve as alternative hosts for YMV and contribute as inoculum sources to secondary dissemination of viruses and reduction in food production.

Table 2. DAS-ELISA absorbance value of Yam samples recorded at one hour post substrate addition and overnight for the two viruses YMV and CMV

\begin{tabular}{llllll}
\hline & & \multicolumn{4}{c}{ Viruses/Absorbance at 450 nm } \\
\cline { 3 - 6 } & & YMV & YMV & CMV & CMV \\
\hline Farm location & District & 1 hour & Overnight & 1 hour & Overnight \\
\hline Wode & North & $0.633(+)$ & $1.485(+)$ & $0.106(-)$ & $0.247(-)$ \\
Magya & North & $0.509(+)$ & $1.539(+)$ & $0.099(-)$ & $0.220(-)$ \\
Dzwajiwo & North & $0.662(+)$ & $1.191(+)$ & $0.102(-)$ & $2.241(+)$ \\
Kaiama & North & $0.641(+)$ & $1.655(+)$ & $0.101(-)$ & $0.212(-)$ \\
Alapa & North & $0.663(+)$ & $0.934(+)$ & $0.117(-)$ & $0.844(+)$ \\
Okuta & North & $0.760(+)$ & $1.910(+)$ & $0.157(-)$ & $0.204(-)$ \\
Gobi & North & $0.493(+)$ & $1.161(+)$ & $0.120(-)$ & $0.265(-)$ \\
Gwanara & North & $0.662(+)$ & $1.128(+)$ & $0.114(-)$ & $0.258(-)$ \\
Kosubosu & North & $0.541(+)$ & $0.965(+)$ & $0.113(-)$ & $0.277(-)$ \\
Teshe & North & $0.677(+)$ & $1.220(+)$ & $0.106(-)$ & $0.724(+)$ \\
Bioweite & North & $0.542(+)$ & $0.859(+)$ & $0.117(-)$ & $0.299(-)$ \\
Igbogi & North & $0.637(+)$ & $1.122(+)$ & $0.123(-)$ & $0.364(-)$ \\
Sebo & North & $0.519(+)$ & $1.157(+)$ & $0.619(+)$ & $2.328(+)$ \\
Kemanji & North & $0.538(+)$ & $1.163(+)$ & $0.102(-)$ & $0.242(-)$ \\
Ilesha & North & $0.603(+)$ & $1.170(+)$ & $0.108(-)$ & $0.268(-)$ \\
Kuliji & North & $0.547(+)$ & $1.120(+)$ & $0.103(-)$ & $0.235(-)$ \\
Bani & North & $0.762(+)$ & $0.809(+)$ & $0.109(-)$ & $0.271(-)$ \\
Woro & North & $0.617(+)$ & $1.183(+)$ & $0.505(+)$ & $1.262(+)$ \\
Shonga & North & $0.714(+)$ & $0.939(+)$ & $0.125(-)$ & $0.291(-)$ \\
Lafiagi & North & $0.585(+)$ & $1.178(+)$ & $0.721(+)$ & $1.304(+)$ \\
Osin/Agogo & Central & $0.706(+)$ & $1.105(+)$ & $0.136(-)$ & $0.320(-)$ \\
Aleara & Central & $0.823(+)$ & $1.122(+)$ & $0.133(-)$ & $0.305(-)$ \\
\hline
\end{tabular}




\begin{tabular}{|c|c|c|c|c|c|}
\hline Afon & Central & $0.469(+)$ & $0.961(+)$ & $0.119(-)$ & $0.256(-)$ \\
\hline Lasoju & Central & $0.682(+)$ & $1.107(+)$ & $0.109(-)$ & $0.806(+)$ \\
\hline Owode & Central & $0.822(+)$ & $0.909(+)$ & $0.155(-)$ & $0.430(-)$ \\
\hline Onire & Central & $0.981(+)$ & $1.138(+)$ & $0.130(-)$ & $0.308(-)$ \\
\hline Sapati Ile & Central & $0.821(+)$ & $1.137(+)$ & $0.133(-)$ & $0.261(-)$ \\
\hline Ago Oja & Central & $0.549(+)$ & $0.918(+)$ & $0.114(-)$ & $0.271(-)$ \\
\hline Budo Alfa & Central & $0.492(+)$ & $1.124(+)$ & $0.129(-)$ & $0.336(-)$ \\
\hline Fufu & Central & $0.686(+)$ & $1.108(+)$ & $0.610(+)$ & $0.925(+)$ \\
\hline Laduba & Central & $0.713(+)$ & $0.927(+)$ & $0.122(-)$ & $0.264(-)$ \\
\hline Temidire & Central & $0.690(-)$ & $0.877(+)$ & $0.133(-)$ & $0.284(-)$ \\
\hline Gaa Adio & Central & $0.619(+)$ & $0.957(+)$ & $1.120(+)$ & $2.244(+)$ \\
\hline Budo Adan & Central & $0.510(+)$ & $1.109(+)$ & $0.125(-)$ & $0.314(-)$ \\
\hline Gaa Jawuro & Central & $0.874(-)$ & $1.123(+)$ & $0.116(-)$ & $0.267(-)$ \\
\hline Lanwa & Central & $0.938(-)$ & $1.108(+)$ & $0.108(-)$ & $0.248(-)$ \\
\hline Molete & Central & $0.474(+)$ & $0.951(+)$ & $0.117(-)$ & $0.912(+)$ \\
\hline Oloru & Central & $0.666(+)$ & $0.907(+)$ & $0.127(-)$ & $0.320(-)$ \\
\hline Paiye & Central & $0.586(+)$ & $0.906(+)$ & $0.106(-)$ & $0.229(-)$ \\
\hline Ejidon Gari & Central & $0.694(+)$ & $1.101(+)$ & $0.107(-)$ & $0.260(-)$ \\
\hline Omupo & South & $0.528(+)$ & $1.107(-)$ & $0.117(-)$ & $0.193(-)$ \\
\hline Ilofa & South & $0.835(+)$ & $1.229(+)$ & $0.100(-)$ & $0.306(-)$ \\
\hline Osi & South & $0.646(+)$ & $1.194(+)$ & $0.123(-)$ & $0.287(-)$ \\
\hline Ajase-Ipo & South & $0.543(+)$ & $1.169(+)$ & $0.129(-)$ & $0.300(-)$ \\
\hline Oke-Onigbin & South & $0.549(+)$ & $1.176(+)$ & $0.108(-)$ & $0.235(-)$ \\
\hline Edidi & South & $0.486(+)$ & $0.758(+)$ & $0.107(-)$ & $0.239(-)$ \\
\hline Eruku & South & $0.658(+)$ & $1.137(+)$ & $0.508(+)$ & $2.230(+)$ \\
\hline Obo & South & $0.488(+)$ & $1.165(+)$ & $0.129(-)$ & $0.382(-)$ \\
\hline Araromi-opin & South & $0.449(+)$ & $1.150(+)$ & $0.141(-)$ & $0.494(-)$ \\
\hline Agunjin-Ora & South & $0.299(+)$ & $0.336(+)$ & $0.103(-)$ & $0.198(-)$ \\
\hline Idofian & South & $0.645(+)$ & $1.135(-)$ & $0.102(-)$ & $0.202(-)$ \\
\hline Igbaja & South & $0.806(+)$ & $1.212(+)$ & $1.101(+)$ & $2.218(+)$ \\
\hline Ijara-Isin & South & $0.208(-)$ & $0.285(-)$ & $0.118(-)$ & $0.357(-)$ \\
\hline Esie-Ijan & South & $0.624(+)$ & $0.980(+)$ & $0.111(-)$ & $0.291(-)$ \\
\hline Offa & South & $0.516(+)$ & $0.751(+)$ & $0.117(-)$ & $0.363(-)$ \\
\hline Ira & South & $0.169(-)$ & $0.314(-)$ & $0.093(-)$ & $0.189(-)$ \\
\hline Ora & South & $0.761(+)$ & $1.130(+)$ & $0.098(-)$ & $0.191(-)$ \\
\hline Isapa & South & $0.632(+)$ & $1.144(+)$ & $0.103(-)$ & $0.234(-)$ \\
\hline Omu-Aran & South & $0.950(-)$ & $1.117(+)$ & $0.103(-)$ & $0.195(-)$ \\
\hline Koro & South & $0.611(+)$ & $0.877(+)$ & $0.908(+)$ & $1.314(+)$ \\
\hline Positive control & & 1.527 & 3.346 & 2.611 & 3.376 \\
\hline Negative control & & 0.241 & 0.102 & 0.111 & 0.107 \\
\hline Buffer & & 0.174 & 0.968 & 0.008 & 0.006 \\
\hline
\end{tabular}

YMV = Yam Mosaic Virus, CMV= Cucumber Mosaic Virus, (+) denotes virus presence, (-) denotes virus absence 
Table 3. DAS-ELISA absorbance value of weed species on yam fields recorded overnight post substrate addition for the two viruses YMV and CMV

\begin{tabular}{|c|c|c|c|c|c|}
\hline \multirow[b]{2}{*}{ Family } & \multirow[b]{2}{*}{ Weed species } & \multicolumn{4}{|c|}{ VIRUSES/Absorbance at $450 \mathrm{~nm}$} \\
\hline & & MG & LC & YMV & CMV \\
\hline Acanthaceae & Justicia flava (Forssk) Vahl & $\mathrm{B}$ & $\mathrm{P}$ & $0.177(-)$ & $0.129(-)$ \\
\hline Amarantheceae & Gomphrena celosioides Mart & $\mathrm{B}$ & $\mathrm{P}$ & $0.163(-)$ & $0.128(-)$ \\
\hline \multirow[t]{7}{*}{ Asteraceae } & Acanthospermum hispidium DC & $\mathrm{B}$ & A & $0.193(-)$ & $0.100(-)$ \\
\hline & Ageratum conyzoides L. & $\mathrm{B}$ & A & $0.162(-)$ & $0.128(-)$ \\
\hline & Eclipta alba L. & $\mathrm{B}$ & A & $0.753(+)$ & $0.124(-)$ \\
\hline & E. prostrata L. & $\mathrm{B}$ & A & $0.160(-)$ & $0.142(-)$ \\
\hline & Melampodium divaricatum $\mathrm{L}$. & $\mathrm{B}$ & A & $0.304(+)$ & $0.146(-)$ \\
\hline & Vernonia parrottetii Sch.Bip. ex Walp & $\mathrm{B}$ & A & $0.289(+)$ & $0.116(-)$ \\
\hline & Conyza sumatrensis (Retz.) E. Walker & $\mathrm{B}$ & A & $0.132(-)$ & $0.103(-)$ \\
\hline \multirow{4}{*}{ Cypearaceae } & Cyperus esculentus L. & S & $\mathrm{P}$ & $0.237(-)$ & $0.118(-)$ \\
\hline & C. iria $\mathrm{L}$. & $S$ & $\mathrm{P}$ & $0.166(-)$ & $0.115(-)$ \\
\hline & C. rotundus L. & $S$ & $\mathrm{P}$ & $0.296(-)$ & $0.111(-)$ \\
\hline & Mariscus flabelliformis Kunth & $\mathrm{S}$ & $\mathrm{P}$ & $0.402(+)$ & $0.199(-)$ \\
\hline \multirow[t]{3}{*}{ Euphorbiaceae } & Phyllanthus amarus Schum \& Thonn & $\mathrm{B}$ & A & $0.429(+)$ & $0.115(-)$ \\
\hline & Euphorbia heterophylla L. & $\mathrm{B}$ & A & $0.611(+)$ & $0.096(-)$ \\
\hline & Croton hirtus L'Her & $\mathrm{B}$ & A & $0.162(-)$ & $0.136(-)$ \\
\hline \multirow[t]{2}{*}{ Fabaceae } & Chamaecrista mimosoides L. & $\mathrm{B}$ & $\mathrm{A} / \mathrm{P}$ & $0.201(-)$ & $0.119(-)$ \\
\hline & Desmodium tortuosum (Sw.) DC. & B & A & $0.174(-)$ & $0.121(-)$ \\
\hline Lamiaceae & Hyptis spicigera Lam & $\mathrm{B}$ & A & $0.202(-)$ & $0.107(-)$ \\
\hline Loganiaceae & Spigelia anthelmia L. & $\mathrm{B}$ & $\mathrm{A}$ & $0.310(+)$ & $0.118(-)$ \\
\hline Malvaceae & Sida garckeana Polak & $\mathrm{B}$ & $\mathrm{A} / \mathrm{P}$ & $0.164(-)$ & $0.116(-)$ \\
\hline \multirow[t]{5}{*}{ Poaceae } & Leptochloa caerulescens Steud. & G & A & $0.189(-)$ & $0.137(-)$ \\
\hline & Acroceras zizaniodes Kunth Dandy & G & $\mathrm{P}$ & $0.150(-)$ & $0.115(-)$ \\
\hline & Cynodon dactylon (L.) Pers. & G & $\mathrm{P}$ & $0.437(+)$ & $0.148(-)$ \\
\hline & Eleusine indica (L) Gaertn & $\mathrm{G}$ & A & $0.238(-)$ & $0.112(-)$ \\
\hline & Eragrostis tenella (A.Rich.) Hochst & G & A & $0.219(-)$ & $0.138(-)$ \\
\hline
\end{tabular}




\begin{tabular}{|c|c|c|c|c|c|}
\hline \multirow{6}{*}{ Rubiaceae } & Brachiaria deflexa (Schumach) C.E. & G & A & $0.123(-)$ & $0.108(-)$ \\
\hline & Mitracarpus villosus (Sw) Dc & $\mathrm{B}$ & A & $0.186(-)$ & $0.112(-)$ \\
\hline & Oldenlanda herbacea (L.) Roxb & $\mathrm{B}$ & $\mathrm{A} / \mathrm{P}$ & $0.471(+)$ & $0.193(-)$ \\
\hline & Positive control & & & 2.264 & 3.432 \\
\hline & Negative control & & & 0.112 & 0.111 \\
\hline & Buffer & & & 0.009 & 0.100 \\
\hline
\end{tabular}

\section{CONCLUSION}

It can be concluded from this study that there was a prevalence of YMV and CMV in the yam species (Discorea rotundata and Discorea alata), with variations in the occurrence and intensity of virus diseases among the districts in the study area. Eclipta alba, Euphorbia heterophylla, Oldenlandia herbacea, Cynodon dactylon and Phyllantus amarus can be naturally infected by YMV in the field and thus, acting as YMV reservoir to infect yam. Yam is an attractive crop among poor farmers with limited resources and its availability all year round makes it an important food security crop. There is therefore, an urgent need for efficient management strategies for virus and weed elimination within and around yam fields in the Southern Guinea Savannah Agroecology of Kwara State, Nigeria.

\section{REFERENCES}

Abraham, P., Banwo, O. O., Kashina, B. D. and Alegbejo, M.D. (2020). Occurrence, distribution and alternative hosts of wheat streak mosaic virus infecting ginger in Kaduna State, Nigeria. Journal of Agriculture and Rural Development in the Tropics and Subtropics, 121(1): 127133.

Akanji, B. O., Akpokodje, G. and Ogundele, O. O. (2003). Labour use pattern on farms. NISER, Annual Survey of Crop Production Condition in Nigeria, 34-46.

Akobundu, I.O., Ekeleme, F., Agyakwa, C.W., \& Ogazie, C.A. (2016). A Handbook of West African Weeds. International institute of tropical agriculture, Ibadan, Nigeria, pp. 1-381. 
Asala S.W. and Ebukiba, E.S. (2016). Profitability of yam production in Southern Guinea Savanna zone of Nigeria. Net Journal of Agricultural Science, 4(1): 9-14.

Asala, S., Alegbejo, M. D., Kashina, B., Banwo, O. O., Asiedu, R. and Kumar, L. (2012). Distribution and incidence of viruses infecting yam (Dioscorea spp.) in Nigeria. Global Journal of Bio-Science and BioTechnology, 1(2): 163-167.

Asala, S., Alegbejo, M. D., Kashina, B. D., Banwo, O. O. and Shinngu, C. P. (2014). Viruses in weeds in Dioscorea yam fields in Nigeria. African Crop Science Journal, 22(2): 109-115.

Atiri, G.I., Winter, S. and Alabi, O.J. (2003). Yam. In G. Leobenstein and G. Thottappilly (Eds.), Virus and Virus-like Diseases of Major Crops in Developing Countries (pp. 249- 267). Kluwer, Acad Press, Dordrecht, the Netherlands.

Awodoyin, R. O., Akinyemi, C. Y., Bolanle, O. O. and Antiabong, I. C. (2013). Spatial distribution and abundance of Solanecio biafrae (Olive $\&$ Heirne) c. Jeffrey and structure of weed communities in some cocoa plots in Ekiti, Oyo and cross river states, Nigeria. Ife Journal of Science, 15(3): 661-676.

Chaube, H. S. and Pundhir, V. S. (2005). Crop diseases and their management. PHI Learning Pvt. Ltd, New Delhi. Degras, L. (1993). The Yam: A Tropical Root Crop. Macmillan Press, London pp. 144.
Dutta, B. (2015). Food and medicinal values of certain species of Dioscorea with special reference to Assam. Journal of Pharmacognosy and Phytochemistry, 3(4): 15-18.

Ekanayake, I. J. and Asiedu, R. (2003). Problems and perspectives of yambased cropping systems in Africa. Journal of Crop Production, 9(1-2): 531-558.

Eni A. O., Hughes, J., Asiedu R. and Rey, M.E.C. (2013). Incidence and diversity of mixed viruses lower in yam tubers and tuber sprouts compared with field leaf samples: implications for virus-free planting material control strategy. African Journal of Agricultural Research, 8(23): 3060-3067.

Groves, R. L., Walgenbach, J. F., Moyer, J. W. and Kennedy, G. G. (2002). The role of weed hosts and tobacco thrips, Frankliniella fusca, in the epidemiology of tomato spotted wilt virus. Plant Disease, 86(6): 573582.

Gumedzeo, Y.M. (2002). Major virus diseases of medicinal plants in West Africa. Archives of Virology, 147(10): 1855-1867.

Hgaza, V. K., Diby, L. N., Assa, A. and Ake, S. (2010). How fertilization affects yam (Dioscorea alata L.) growth and tuber yield across the years. African Journal of Plant Science, 4(3): 053-060.

Hily, J. M., Garcia, A., Moreno, A., Plaza, M., Wilkinson, M. D., Fereres, A., Fraile, A. and Garcia-Arenal, F. 
(2014). The relationship between host lifespan and pathogen reservoir potential: an analysis in the system Arabidopsis thalianacucumber mosaic virus. PLOS Pathogens, 10(11): e1004492.

Ita, E. E., Uyoh, E. A., Nakamura, I. and Ntui, V. O. (2020). Efficient elimination of Yam mosaic virus (YMV) from white yam (Dioscorea rotundata Poir.) by cryotherapy of axillary buds. South African Journal of Botany, 130: 123-129.

Kolombia, Y. A., Karssen, G., Viaene, N., Kumar, P. L., De Sutter, N., Joos, L., Coyne, D.L. and Bert, W. (2017). Diversity of root-knot nematodes associated with tubers of yam (Dioscorea spp.) established using isozyme analysis and mitochondrial DNA-based identification. Journal of Nematology, 49(2): 177.

Kumar, P. L. (2009). Methods for the diagnosis of plant virus diseases: laboratory manual. International Institute of Tropical Agriculture (IITA), Ibadan, Nigeria, pp. 1-90.

Mukhtar, S. M., Banwo, O. O., Kashina, B. D. and Alegbejo, M. D. (2012). Occurrence of viruses infecting yam in kaduna State, Nigeria. Nigerian Journal of Plant Protection, 26(1): 1017.

Obidiegwu, J. E. and Akpabio, E. M. (2017). The geography of yam cultivation in southern Nigeria: exploring its social meanings and cultural functions. Journal of Ethnic Foods, 4(1): 28-35.
Odedara, O. O., Hughes, J. D. A., Odebode, A. C. and Odu, B. O. (2008). Multiple virus infections of lablab (Lablab purpureus (L.) Sweet) in Nigeria. Journal of General Plant Pathology, 74(4): 322-325.

Odu, B. O., Hughes, J. D. A., Shoyinka, S. A. and Dongo, L. N. (1999). Isolation, characterisation and identification of a poty virus from Dioscorea alata L.(water yam) in Nigeria. Annals of Applied Biology, 134(1): 65-71.

Osei, K., Ennin, S. A., Aighewi, B., Aidoo, A.K., Lamptey, J.N.L., Mochiah, M.B., Aihebhoria, D., Adomako, J., Appiah-Kubi, Z., Mensah, G.O. and Asante, B.O (2019). Enhancing productivity of farmer-saved seed yam in Ghana: positive selection and neem leaf powder factors. African Crop Science Journal, 27(4): 631-640.

Preller, K. H., Schilbach, L., Pokorny, T., Flemming, J., Seifritz, E. and Vollenweider, F. X. (2018). Role of the 5-HT2A receptor in self-and other-initiated social interaction in lysergic acid diethylamide-induced states: a pharmacological fMRI study. Journal of Neuroscience, 38(14): 3603-3611.

Rybicki, E. P. (2015). A top ten list for economically important plant viruses. Archives of Virology, 160(1): 17-20.

Singh, A., Singh, M. and Singh, D. V. (1986). The successful use of 
intercropping for weed management in medicinal yam (Dioscorea floribunda Mart and Gal). International Journal of Pest Management, 32(2): 105-107.

Toualy, M.N.Y., Diallo, H.A., Akinbade, S.A., Seka, K. and Lava Kumar, P. (2014). Distribution, incidence and severity of viral diseases of yam (Dioscorea spp.) in Côte d'Ivoire. African Journal of Biotechnology, 13(3): 465-470.

Udoh, J., Ndon, B. A., Asuquo, P. E. and Ndaeyo, N. U. (2005). Crop production techniques for the tropics. Concept publications limited, Munshin, Lagos Nigeria, 101-106.

Umar, A., Nwator, G., Likita, M. S. and Adoko, S. (2006). The indigenous yam storage technology and postharvest losses in Nigeria: the Benue state perspective. International Journal of Food and Agricultural Research, 5(2): 113-139.

Yeyeh, T. M. N., Diallo, H. A., Akinbade, S. A., Séka, K. and Kumar, P. L. (2014). Distribution, incidence and severity of viral diseases of yam (Dioscorea spp.) in Côte d'Ivoire. African Journal of Biotechnology, 13(3). 